\title{
The Effect of Teacher's Mathematical Knowledge on Self-efficacy for Teaching Mathematics
}

\author{
Sugilar \\ Department of Mathematics and Sciences Education \\ Faculty of Education and Teacher Training \\ Universitas Terbuka \\ Tangerang Selatan, Indonesia
}

\begin{abstract}
The purpose of this research was to explore the effect of teachers' mathematical knowledge on self-efficacy for teaching mathematics. The framework of teacher's mathematical knowledge broadened in scope from teachers' common mathematical knowledge, specialized mathematical knowledge, to horizon mathematical knowledge. These three were modeled and integrated into the teaching of the division of fractional numbers. The method used in this research was quasi-experiment that involved 42 teachers of elementary schools. Path analysis was applied to data that included the direct or indirect effects of mathematical knowledge on self-efficacy. Results indicate that horizon mathematical knowledge was statistically significant and positive for self-efficacy for teaching mathematics $(\beta=0.657$, $p=0.000$ ). Significant statistic was also shown in the effect of horizon mathematical knowledge on both common mathematical knowledge $(\beta=0.362, p=0.019)$ and specialized mathematical knowledge $(\beta=0.574, p=0.000)$. However, the effect of both common mathematical knowledge $(\beta=0.093, p=0.509)$ and specialized mathematical knowledge $(\beta=0.029, p=0.857)$ on selfefficacy for teaching mathematics was not statistically so. The importance of building self-efficacy in the current workforce of mathematics teacher through a wide range of training practices for teacher's horizon mathematical knowledge needs further potential directions, accordingly.
\end{abstract}

Keywords-horizon mathematical knowledge, common mathematical knowledge, specialized mathematical knowledge, selfefficacy for teaching mathematics.

\section{INTRODUCTION}

The success of students' learning depends on many factors, but teachers remain a main factor [1]. An educational expert stated, in response to the results of TIMSS, that poor standards for teacher competence were bound to set off low-quality mathematics teaching in Indonesia. Another expert asserted that, with respect to 2013 Curriculum, a teacher was the key to what might sustain or hinder a successful curriculum implementation - a professional teacher would be able to integrate ineffective curriculum into meaningful learning [2]. In a similar sense, Minister of Education and Culture of Indonesia stated that the quality of teachers defines the notion of what makes the nation in the future [3]. This importance of teacher competencies has strong implications for student learning and achievement, including mathematics achievement.
A sense of self-efficacy for a teacher constitutes a selfperception toward his or her capability of organizing an activity and achieving a teaching goal successfully. As such, Selfefficacy for teaching Mathematics specifically refers to an effective trait for a teacher associated with his or her competency upon teaching mathematics. Self-efficacy has been extensively researched based on the assumption that learning outcome is subject to SETM, which can be developed in many ways. One of them was observed by Giles, Byrd, \& Bendolph [4] in their experimental study who claimed that, through training of constructivist-based elementary mathematics, SETM improved significantly.

\section{LITERATURES REVIEW}

\section{A. Self-Efficacy for Teaching Mathematics}

Bandura defined self-efficacy as people's beliefs in their capabilities to produce given attainments [5]. Accordingly, Safak, Oktay, Harun, \& Fulya described self-efficacy for teaching as teachers' self-perception toward their capability of organizing an activity and achieving performance at a certain quality level [6]. In terms of mathematics teaching, self-efficacy refers to a perceived capability to conduct mathematics teaching in ways that are effective and efficient [7]. It is important to note that Self-Efficacy for Teaching Mathematics (SETM) is different from the typical concept of teacher competence, as Zuya, Kwalat, \& Attah [8] stated that “A teacher's self-efficacy goes beyond just having professional knowledge and skills; it is also the belief that one has the capability to put his or her professional knowledge and skills into action.” (p.32)

SETM has sparked a sprawling line of researches into how teachers' SETM contribute to students' learning results and even to students' self-efficacy itself. For instance, Zee \& Komen [9] has concluded that self-efficacy for teaching accounted for the quality of classroom teaching and learning, students' learning results, and teachers' satisfaction.

In relation to teacher's performance, Pendergast, Garvis \& Keogh [10] asserted that high self-efficacy in teachers encouraged teachers' persistence and resilience to accomplish students' learning needs. Plourde [11] found that teachers with a strong sense of self-efficacy demonstrated different teaching methods, engaged in researches to advance effectiveness of 
those methods, and chose to engage in tasks that fostered student-centered teaching strategy. The counterparts with a weak sense of self-efficacy, by ccontrast, operated a learning setting with teacher-centered instructions and book-based inputs.

Zee \& Komen [12] illustrated the relationship between selfefficacy and quality of classroom teaching, student learning results, teacher's satisfaction, and teacher's well-being in Figure 1.

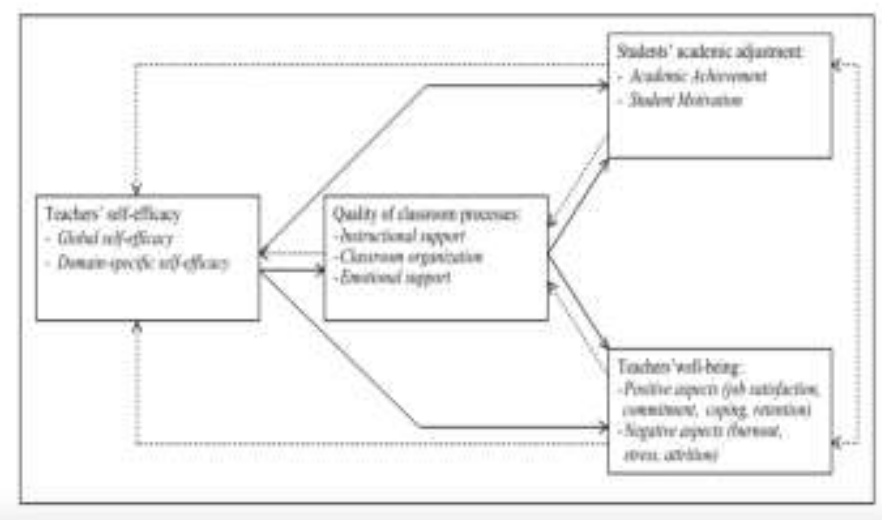

Fig 1. Relationship Self-efficacy for teaching and quality of teaching

\section{B. Mathematical Knowledge for Teaching}

Mathematical knowledge for teaching comes down to two main components, i.e. subject matter knowledge and pedagogical content knowledge, as Ball, Thames, and Phelps [13] displayed in Figure 2.

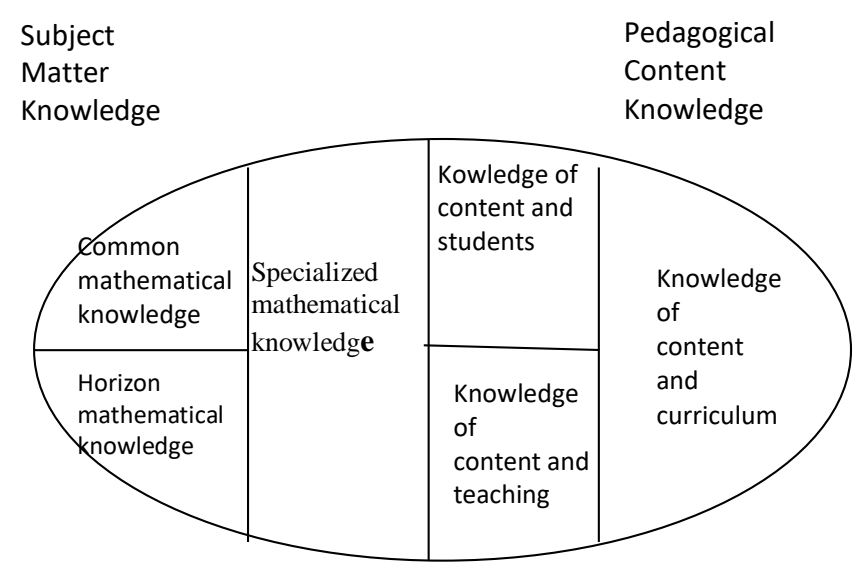

Fig 2. Mathematical Knowledge for Teaching [13]

This research focused on subject matter knowledge that was identified with three specific domains-common mathematical knowledge, specialized mathematical knowledge, and horizon mathematical knowledge.

\section{1) Common Mathematical Knowledge}

Common mathematical knowledge, as its name suggests, is mathematical knowledge which is commonly delivered to students in a teaching process. At the end of a mathematics teaching process, the students were supposed to comprehend common mathematical knowledge listed on the learning goal. Livy, Vale, \& Herbert [14] asserted that common mathematical knowledge allows teachers to know the content areas that they teach. In 2013 curriculum for SD/MI (Elementary Schools/ Madrasah Ibtidaiyah), fractions were introduced in third grade. Basic competencies of SD/MI from grade III to grade VI are presented in Table 1.

TABLE 1

BASIC COMPETENCIES OF FRACTIONS

IN 2013 CURRICULUM FOR GRADE III-IV

\begin{tabular}{|c|c|}
\hline Grade & Basic Competencies \\
\hline III & $\begin{array}{l}\text { - Understanding basic fractions by using visual models } \\
\text { (concrete objects and pictures) and ordering as well as } \\
\text { comparing fractions from least to greatest } \\
\text { Identifying fractions and decimals and applying } \\
\text { addition and substraction of fractions with like } \\
\text { denominators }\end{array}$ \\
\hline IV & $\begin{array}{ll}\text { - } & \text { Recognizing equivalent fractions and applying } \\
\text { operations with fractions by using visual models } \\
\text { - } & \text { Understanding equivalent fractions and operations } \\
\text { with fractions by using visual models } \\
\text { - } \quad \text { Converting fractions into decimals and percentages } \\
\text { - } \quad \begin{array}{l}\text { Extracting a fraction as a result of addition or } \\
\text { substraction of two other fractions with a range of } \\
\text { possible answers }\end{array} \\
\end{array}$ \\
\hline V & $\begin{array}{l}\text { Recognizing various types of fractions (common } \\
\text { fractions, mixed fractions, decimals and percentages), } \\
\text { converting fractions into decimals and applying } \\
\text { multiplication and division } \\
\text { - Understanding and applying various types of fractions } \\
\text { (common fractions, mixed fractions, decimals and } \\
\text { percentages) and converting fractions into decimals } \\
\text { Extracting a fraction as a result of addition, } \\
\text { substraction, multiplication and division of two other } \\
\text { fractions expressed as decimals and percentages with a } \\
\text { range of possible answers }\end{array}$ \\
\hline VI & $\begin{array}{l}\text { Understanding operations with various types of } \\
\text { fractions (common fractions, mixed fractions, } \\
\text { decimals and percentages) } \\
\text { Understanding and applying operations with various } \\
\text { types of fractions (common fractions, mixed fractions, } \\
\text { decimals and percentages) }\end{array}$ \\
\hline & istry of Education and Culture [15] \\
\hline
\end{tabular}

Specialized mathematical knowledge for teaching refers to the knowledge and skills teachers require to engage in particular tasks. For instance, teachers verify non formal reasoning through a mathematical problem. When it comes to teaching fraction divisions, teachers also need to extend a vast area of division. Olanoff [16] summarizes the materials current or prospective teachers need to develop in teaching fraction divisions. They are as follows:

- Fractions are often presented with two distinct interpretations, i.e., partitive model (also known as sharing model) and quotitive model (measurement or repeated substraction). 
- In a partitive model of division, problem 20:5 would be solved by splitting 20 items equally to 5 groups at the same time and finding the number of items in each group.

- In a quotitive model of division, problem 20:5 would be solved by taking out a set of 5 items to groups until the items are distributed and counting how many sets of 5 the groups have got.

- Quotitive model would be more efficient for teaching fraction divisions. An example where quotitive model is better than partitive model would go like this; "We have 5 1/2 kilograms of candies. Those are enough to give $1 / 2$ kilogram to each friend. How many friends can we give candies to?" Such problem would be best solved with quotitive model by substracting $51 / 2$ by $1 / 2$ until the whole candies are gone.

- The third model is multiples and factors where division is the inverse of multiplication. A typical word problem would go something like this; "The area of a rectangle is $6 \frac{1}{2}$ meters. If the length is $3 \frac{1}{4}$ meters, what is the width of the rectangle?" Such requires $61 / 2$ divided by $31 / 4$ which equals 2 meters. As division is the opposite of multiplication, the problem can be basically rephrased as "How do we multiply $3 \frac{1}{4}$ to get $6 \frac{1}{2}$ ?"

- Traditional view on invert-and-multiple algorithm would work best with partitive model of division. Here, understanding fraction divisions means understanding the inverse relationship between division and multiplication, where dividing by a number is the same thing as multiplying the inverse of that number.

\section{3) Horizon Mathematical Knowledge}

Horizon mathematical knowledge for teaching is characterized as explicit mathematical knowledge from an advanced standpoint, which may come across indirectly. Jakobsen, Thames, Ribeiro, \& Delaney [17] emphasized that elementary school teachers need to establish advanced contents accessible to mathematical teaching and learning. In this view, engaging in advanced mathematics in relation to that currently taught in the class would lead to; (1) awareness that mathematics has broader disciplinary context; (2) competencies to cultivate intuitive knowledge and contemplative approach toward the mathematical contents being taught; (3) sources that provide a vaster array of mathematical landscapes. However, horizon mathematical knowledge has not garnered much attention in mathematics-teaching platforms, as posited by Mosvold \& Fauskanger [18]; "Although horizon mathematical content knowledge is included in the framework of MKT, and researchers seem to agree about its importance, there is still a lack of empirical evidence both for the existence and importance of this particular aspect of teacher knowledge" (p. 12).

Sugilar [19] identified the conception of horizon mathematical knowledge in terms of its relevance to teaching fraction divisions at elementary schools, and suggested eight key points; (1) formal definition of rational numbers; (2) a set of rational numbers as an infinite and countable set; (3) proof that a set of rational number is countable; (4) operations with rational numbers; (5) equivalence between two rational numbers; (6) equivalence classes of rational numbers in an equivalent relation; (7) a set of rational numbers as a group; (8) division as the inverse of multiplication, i.e.:

$$
a: b=\frac{a}{b}=\frac{a x b^{-1}}{b x b^{-1}}=a x b^{-1}
$$

\section{RESEARCH METHOS}

The strategy for measuring the effect of mathematical knowledge for teaching on teachers' self-efficacy involved quantitative approach and quasi-experiment method. Teachers' common mathematical knowledge, specialized mathematical knowledge, and horizon mathematical knowledge were identified as independent variables, and teachers' self-efficacy for teaching as dependent variable. The procedures of the research are as follows:

- Based on the recommendation from the municipal educational offices, forty-two teachers were selected from two municipals of Jambi province. The selected teachers wouldpartake in training of mathematical knowledge for teaching fractional number division, which consisted of common mathematical knowledge, specialized mathematical knowledge, and horizon mathematical knowledge.

- The training was carried out in eight hours. There were three modules in the training.

- At the end of each module, teachers participating in the training would have a test to examine their comprehension. Therefore, three kinds of score of mathematical knowledge for teaching were obtained at the end of the training. These scores would account for the three independent variables in this research.

- At the end of the training, teachers had a test to measure self-efficacy for teaching fractional number division. The score would account for the dependent variable of this research.

The resulting data was then analyzed by path analysis to explore the relationship among variables. Given that this was not a true experiment, the subjects of the experiment were not randomly assigned-the participating teachers were taken based on the recommendation from the municipal educational office.

\section{RESEARCH RESULTS AND RECOMMENDATION}

\section{A. Data Description}

Data description was presented in Table 2. The average scores of common mathematical knowledge (CMK), specialized mathematical knowledge (SMK), horizon mathematical knowledge (HMK), and self-efficacy for teaching mathematics (SETM) were 6.38, 6.88, 8.69, and 48.17 with standard deviation of $1.681,2.39,4.02$, and 5.40, respectively. 
TABLE 2. DATA DESCRIPTION

\begin{tabular}{|l|l|l|l|l|c|}
\hline Variable & $\mathrm{N}$ & Min. & Max. & Mean & $\begin{array}{c}\text { Std. } \\
\text { Deviation }\end{array}$ \\
\hline CMK & 42 & 3 & 9 & 6.38 & 1.68 \\
SMK & 42 & 2 & 11 & 6.88 & 2.39 \\
HMK & 42 & 2 & 17 & 8.69 & 4.02 \\
SETM & 42 & 40 & 56 & 48.17 & 5.39 \\
\hline
\end{tabular}

The CMK, SMK, and HMK were correlated each other as shown in Table 3. The correlation values were significant. Given the multicollinearity among variables, the analysis of multiple regression was not a suitable tool for analyzing the data. Therefore, further analysis would use path analysis.

TABLE 3. CORRELATION AMONG VARIABLES

\begin{tabular}{|ll|l|l|l|l|}
\hline & & PMU & PMK & PMW & SETM \\
\hline CMC & Pearson Correlation & 1 & $.491^{* *}$ & $.361^{*}$ & $.326^{*}$ \\
& Sig. (2-tailed) & & .001 & .019 & .035 \\
& $\mathrm{~N}$ & 42 & 42 & 42 & 42 \\
\hline SMK & Pearson Correlation & $.491^{* *}$ & 1 & $.574^{* *}$ & $.423^{* *}$ \\
& Sig. (2-tailed) & .001 & & .000 & .005 \\
& $\mathrm{~N}$ & 42 & 42 & 42 & 42 \\
\hline HMK & Pearson Correlation & $.361^{*}$ & $.574^{* *}$ & 1 & $.657^{* *}$ \\
& Sig. (2-tailed) & .019 & .000 & & .000 \\
& $\mathrm{~N}$ & 42 & 42 & 42 & 42 \\
\hline SETM & Pearson Correlation & $.326^{*}$ & $.423^{* *}$ & $.657^{* *}$ & 1 \\
& Sig. (2-tailed) & .035 & .005 & .000 & \\
& $\mathrm{~N}$ & 42 & 42 & 42 & 42 \\
\hline
\end{tabular}

*. Correlation is significant at the 0.05 level (2-tailed).

\section{B. Path Analysis}

Path analysis was applied to explore the causal relationship among variables, i.e. CMK, SMK, HMK, and SETM. The model was developed on the bases of several research results that HMK had an effect on CMK, SMK, and students learning, for instance in Sugilar [20]. The model of path analysis was shown in Figure 2.

As it allowed us to measure the relationship among variables, those four variables were tested using three-step of regression analysis: (1) a multiple regression analysis for CMK, SMK, and HMK to test the effect of variables on SETM, (2) a regression analysis to test the effect of HMK through CMK on SETM, and (3) a regression analysis to test the effect of HMK through SMK on SETM.

\section{1) The effect of CMK, SMK, and HMK to SEMT}

The regression analysis revealed that CMK, SMK, and HMK accounted for SETM by $44.1 \%$. The standardized coefficients of regression were presented in Table 4.
TABLE 4. COEFFICIENT OF REGRESSION

\begin{tabular}{|l|l|l|l|l|c|}
\hline \multirow{2}{*}{$\begin{array}{c}\text { Sources of } \\
\text { Variation }\end{array}$} & \multicolumn{2}{|c|}{$\begin{array}{c}\text { Unstandardized } \\
\text { Coefficients }\end{array}$} & $\begin{array}{c}\text { Standardized } \\
\text { Coefficients }\end{array}$ & & \multirow{2}{*}{ Sig. } \\
\cline { 2 - 6 } & $B$ & $\begin{array}{c}\text { Std. } \\
\text { Error }\end{array}$ & Beta & t-value & Sig. \\
\hline (Constant) & 38.734 & 2.686 & & 14.420 & .000 \\
\hline CMK & .299 & .450 & .093 & .666 & .509 \\
\hline SMK & .066 & .360 & .029 & .182 & .857 \\
\hline HMK & .814 & .200 & .606 & 4.066 & .000 \\
\hline
\end{tabular}

Table 4, in the last column, showed that the effect of CMK and SMK on SETM was not significant, with beta $(\beta)$ values of 0.093 and 0.029 , respectively. The only variable that significantly affected SETM was HMK, with beta $(\beta)$ value of 0.606

\section{2) The effect of HMK on $C M K$ and SMK}

The regression analysis was used for computing the effect of HMK on CMK and SMK, and calculating the effect of HMK on SETM through CMK and SMK. In this case, HMK was taken as an independent variable, while CMK and SMK as a separately dependent variable. The analysis was presented in Table 5 and Table 6.

TABLE 5. EFFECT OF HMK TO CMK

\begin{tabular}{|l|c|c|c|c|c|}
\hline \multirow{2}{*}{$\begin{array}{c}\text { Sources of } \\
\text { Variation }\end{array}$} & \multicolumn{2}{|c|}{$\begin{array}{c}\text { Unstandardized } \\
\text { Coefficients }\end{array}$} & $\begin{array}{c}\text { Standardized } \\
\text { Coefficients }\end{array}$ & & \multirow{2}{*}{ Sig. } \\
\cline { 2 - 6 } & $B$ & $\begin{array}{c}\text { Std. } \\
\text { Error }\end{array}$ & Beta & t-value & Sen \\
\hline (Constant) & 5.071 & .589 & & 8.606 & .000 \\
\hline HMK & .151 & .062 & .361 & 2.445 & .019 \\
\hline
\end{tabular}

Table 5 revealed that HMK gave a significant effect on $\mathrm{CMK}$, represented by $\mathrm{c}=0.361$, where the significance level equals to $0.019(<0.05)$. The $\mathrm{R}^{2}$ value in the regression model indicated by $\mathrm{R}^{2}=(0,361)^{2}=0,13$ means that variation in HMK variable accounted for $13 \%$ of the variation in CMK variable.

As CMK did not have any effect on SETM, measuring the effect of HMK on SETM was not possible (Table 4). The fact that HMK affected CMK, in other words, did not necessarily indicate that CMK would affect SETM.

Table 6 showed that HMK had an effect on SMK, indicated by $\beta=0.574$, which was significant at 0.00 . The $\mathrm{R}^{2}$ value equals to $(0,574)^{2}=0,330$, which means that variation of the HMK variable accounted for $33 \%$ of the variation of the SMK variable.

Owing to the non-existent effect of SMK on SETM, measuring the effect of HMK on SETM through SMK was unlikely, indicating that the relationship between HMK and SMK did not affect SETM.

\begin{tabular}{|l|c|c|c|c|c|}
\multicolumn{7}{c|}{ TABLE 6. EFFECT OF HMK TO SMK } \\
\hline \multirow{4}{*}{$\begin{array}{c}\text { Sources of } \\
\text { Variation }\end{array}$} & $\begin{array}{c}\text { Unstandardized } \\
\text { Coefficients }\end{array}$ & $\begin{array}{c}\text { Standardized } \\
\text { Coefficients }\end{array}$ & & \\
\cline { 2 - 6 } & $B$ & $\begin{array}{c}\text { Std. } \\
\text { Error }\end{array}$ & Beta & t-value & Sig. \\
\hline (Constant) & 3.913 & .735 & & 5.321 & .000 \\
\hline HMK & .342 & .077 & .574 & 4.438 & .000 \\
\hline
\end{tabular}




\section{3) The effect of CMK, SMK, and HMK on SEMT}

Based on the calculation of the $\beta$ s in the discussion above, the path of causal relationship among variables in this research is presented in Figure 2.

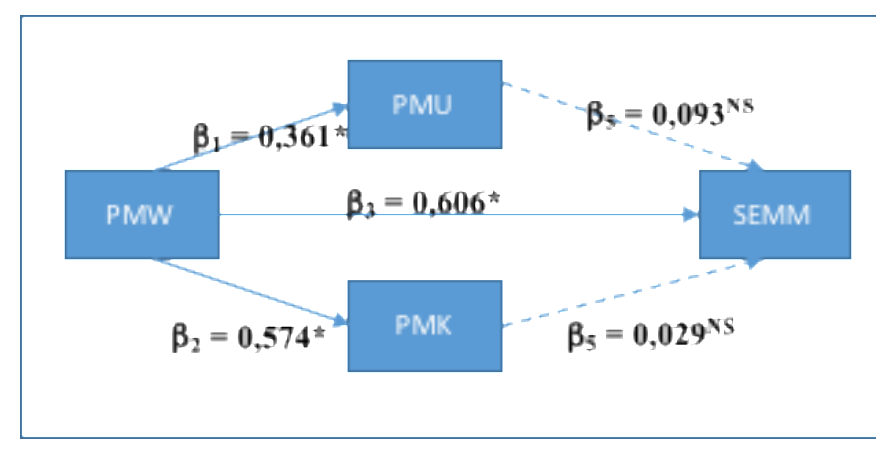

Fig 3. Effect of CMK, SMK, and HMK on SETM

\section{Recommendation}

The research showed that HMK, among other variables, proved the most strongly related to SETM, which, in turn, had an effect on students' learning outcomes, as indicated by a broad set of researches presented previously. HMK had a quite profound correlation and went some distance toward its effect on CMK and SMK as well. As observed in other studies (e.g., Sugilar [21]), CMK, SMK, and HMK, in turn, affected the students' learning too. These studies have raised a strong plausible proposition regarding how HMK considerably mattered for learning quality. This suggests that, while what this research has measured was founded on a strong degree of HMK, the focus of teachers' professional development is to enhance teachers' horizon mathematical knowledge through training or continuing education.

\section{REFERENCES}

[1] Kompas, "Prestasi Sains dan Matematika Indonesia Menurun", Harian Kompas, 14 Desember 2012.

[2] Suyanto, "Guru dalam pembelajaran". Kompas, 1/04/2013.

[3] Republika, "Muhadjir: Kualitas Guru Menentukan Nasib Bangsa", 25 November 2017.

[4] Giles, R.M., Byrd, K. O., and Bendolph, A., "An investigation of elementary preservice teachers' self-e cacy for teaching mathematics", Teacher education \& development, research article, 2016, Cogent Education, 3: 1160523.

[5] Bandura, A. "Self-efficacy: Toward a unifying theory of behavioral change". Psychological Review, 84, 191-215, 1997. Doi:10.1037/0033295X.84.2.191
[6] Safak, U.S., Oktay, A., Harun, B., and Fulya, O.A. "Investigation of the relationship between pre-service science teachers' perceived self-efficacy in science teaching and disposition toward reflective thinking", European Journal of Science and Mathematics Education Vol. 4, No. 3, 331-344, 2016.

[7] Pajares, F. "Overview of social cognitive theory and of self-efficacy". http://www.uky.edu/ eushe2/Pajares/eff.html, 2002.

[8] Zuya, H.E., Kwalat, S.K., \& Attah, B.G. "Pre-service Teachers' Mathematics Self-efficacy and Mathematics Teaching Self-efficacy". Journal of Education and Practice, 7(14), 93-98, 2016.

[9] Zee, M., \& Koomen, H.M.Y. "Teacher Self-Efficacy and Its Effects on Classroom Processes, Student Academic Adjustment, and Teacher WellBeing: A Synthesis of 40 Years of Research", Review of Educational Research, 86(4), pp. 981-1015, 2016.

[10] Pendergast, D., Garvis, S., \& Keogh, J. "Pre-service student-teacher selfefficacy beliefs: An insight into the making of teachers". Australian Journal of Teacher Education, 36, 46-57, 2011.

[11] Plourde, Lee A. "The Influence of Student Teaching on Preservice Elementary Teachers Science Self-Efficacy and Outcome Expectancy Beliefs", Journal of Instructional Psychology; Milwaukee, Wis. Vol. 29, Iss. 4, (Dec 1, 2002): 245.

[12] Zee, M., \& Koomen, H.M.Y. "Teacher Self-Efficacy and Its Effects on Classroom Processes, Student Academic Adjustment, and Teacher WellBeing: A Synthesis of 40 Years of Research". Review of Educational Research, 86(4), pp. 981-1015, 2016.

[13] Ball, D. L., Bass, H., Sleep, L., \& Thames, M. (2005). A theory of mathematical knowledge for teaching. Paper presented at the The Fifteenth ICMI Study: The Professional Education and Development of Teachers of Mathematics, 15-21 May 2005, State University of Sao Paolo at Rio Claro, Brazil.

[14] Livy, S. L., Vale, C., \& Herbert, S. "Developing Primary Pre-service Teachers' Mathematical Content Knowledge During Practicum Teaching". Australian Journal of Teacher Education, 41(2), 2016).

[15] Kementerian Pendidikan dan Kebudayaan .(2013). Kompetensi inti Kompetensi dasar SD. http://kurikulum.kemdikbud.go.id/downloads.

[16] Olanoff, Dana E. "Mathematical Knowledge for Teaching Teachers: The Case of Multiplication and Division of Fractions", Mathematics Dissertations. Paper 64, 2011.

[17] Jakobsen, A., Thames, M. H., Ribeiro, C. M., \& Delaney, S. "Using practice to define and distinguish horizon content knowledge". In Proceeding of the 12th International Congress on Mathematics Education, 8th-15th July, 2012 (pp. 4635 - 4644), COEX, Seoul, Korea, 2012.

[18] Mosvold, R., \& Fauskanger, J. "Translating and Adapting the Mathematical Knowledge for Teaching (MKT) Measures: The Cases of Indonesia and Norway", The Mathematics Enthusiast, ISSN 1551-3440, Vol. 9, nos.1\&2, pp.149-178, 2012.

[19] Sugilar. "Identification of horizon mathematical knowledge for teaching fraction division at elementary schools". IEJME-Mathematics Education, 11(8), 3160-3175, 2016.

[20] Sugilar. "Interaksi antar Variabel Pengetahuan Matematika untuk Mengajar dalam Mempengaruhi Hasil Belajar Siswa", paper presented at Seminar Nasional Matematika IndoMS Wilayah Sulawesi, 11-12 Juli 2017, Universitas Hasanuddin, Makassar.

[21] Sugilar.. "Pengaruh Pengetahuan Matematika untuk Mengajar terhadap Hasil Belajar Siswa", paper presented at Seminar Nasional Matematika, 11 Februari 2017, Universitas Indonesia, Depok. 